\title{
Length Change and Strength Development of Candidate Cement-Based Sealing Mixtures for the WIPP
}

\author{
by Toy S. Poole, Lillian D. Wakeley \\ Structures Laboratory
}

Approved For Public Release; Distribution Is Unlimited

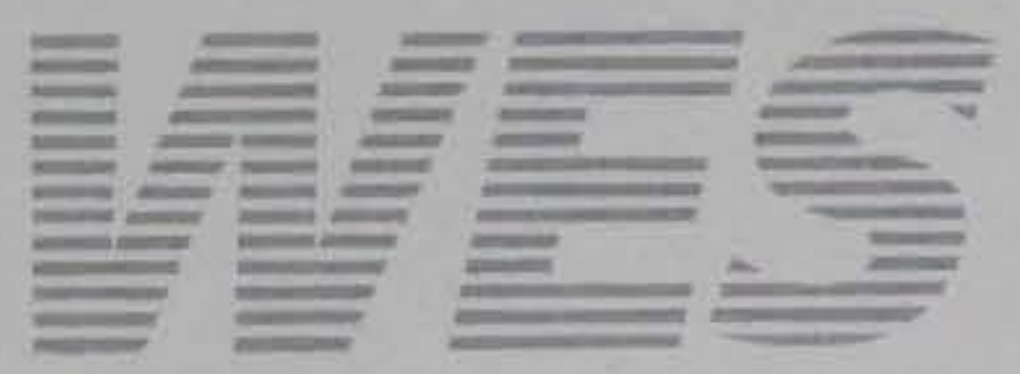

RESEARCH LIBRARY

US ARMY ENGINEER WATERWAYS

EXPERIMENT STATION

VICKSBURG, MISSISSIPPI 


\title{
Length Change and Strength Development of Candidate Cement-Based Sealing Mixtures for the WIPP
}

\author{
by Toy S. Poole, Lillian D. Wakeley \\ Structures Laboratory \\ U.S. Army Corps of Engineers \\ Waterways Experiment Station \\ 3909 Halls Ferry Road \\ Vicksburg, MS 39180-6199
}

Final report

Approved for public release; distribution is unlimited

Prepared for U. S. Army Corps of Engineers

Washington, DC 20314-1000 


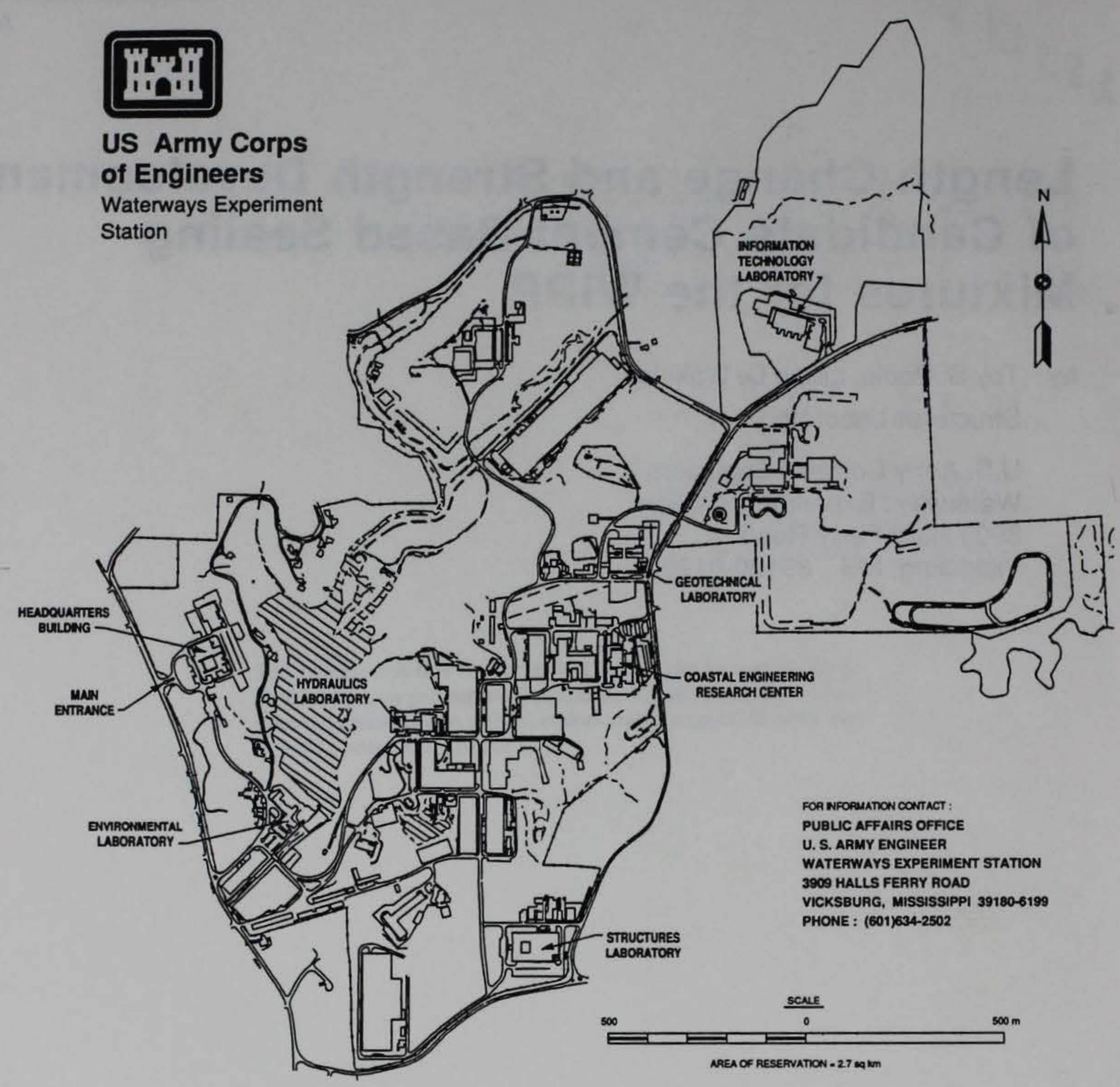

\section{Waterways Experiment Station Cataloging-in-Publication Data}

Poole, Toy S. (Toy Spotswood), 1946-

Length change and strength development of candidate cement-based sealing mixtures for the WIPP / by Toy S. Poole, Lillian D. Wakeley ; prepared for U.S. Army Corps of Engineers.

34 p. : ill. ; $28 \mathrm{~cm}$. - (Technical report ; SL-93-4) Includes bibliographical references.

1. Expansive concrete. 2. Grout (Mortar) 3. Radioactive waste disposal in the ground. 4. Concrete - Expansion and contraction I. Wakeley, Lillian D. II. United States. Army. Corps of Engineers. III. U.S. Army Engineer Waterways Experiment Station. IV. Title. V. Series: Technical report (U.S. Army Engineer Waterways Experiment Station) ; SL-93-4.

TA7 W34 no.SL-93-4 


\section{Contents}

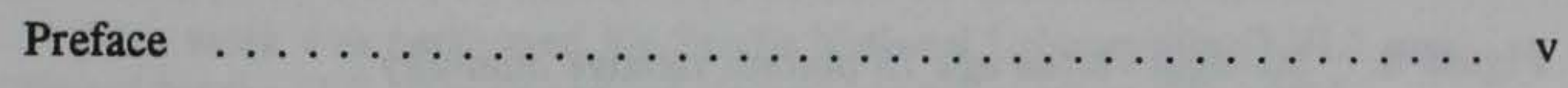

1-Introduction $\ldots \ldots \ldots \ldots \ldots \ldots \ldots \ldots \ldots \ldots \ldots \ldots \ldots \ldots \ldots$

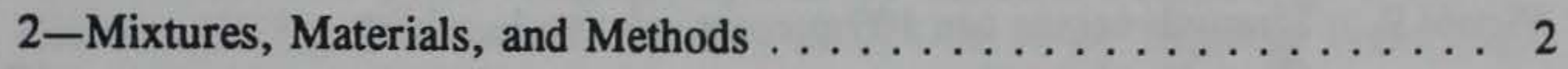

3-Results $\ldots \ldots \ldots \ldots \ldots \ldots \ldots \ldots \ldots \ldots \ldots \ldots$

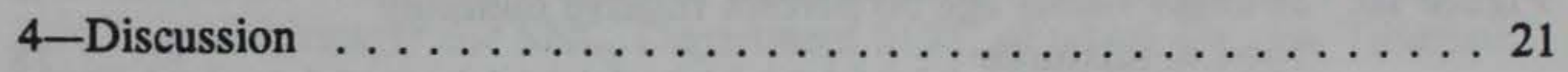

Previous Work at WES Involving Restrained Expansion of Candidate Mixtures . . . . . . . . . . . . . 21

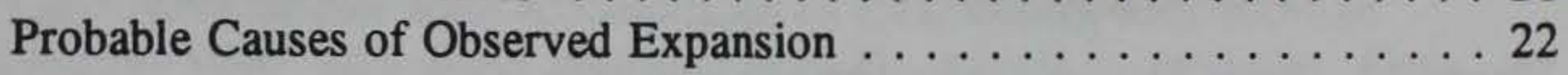

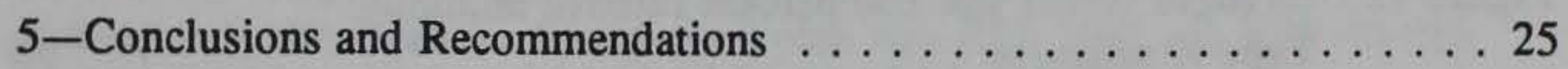

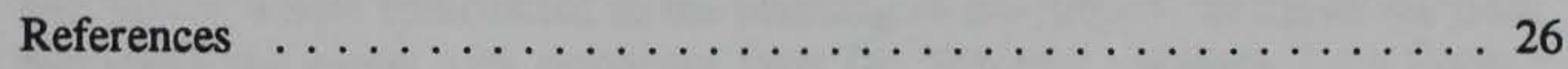

SF 298

\section{List of Tables}

Table 1. Length-Change Data, Class H Cement Mixtures . . . . . . 4

Table 2. Length-Change Data, Type K Cement Mixtures . . . . . . 5

Table 3. Compressive-Strength Data, Class H Cement Mixtures . . . . . 6

Table 4. Compressive-Strength Data, Type K Cement Mixtures ..... 7

\section{List of Figures}

Figure 1. Expansion versus age 50 percent relative humidity Class $\mathrm{H}$ cement . . . . . . . . . . . . . . 9

Figure 2. Expansion versus age 75 percent relative humidity Class $\mathrm{H}$ cement . . . . . . . . . . . . . . 10 
Figure 3. Expansion versus age 100 percent relative humidity

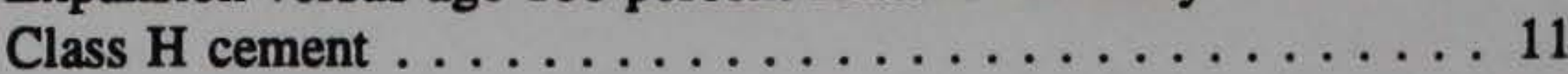

Figure 4. Expansion versus age 50 percent relative humidity

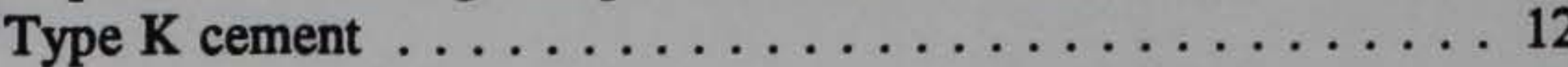

Figure 5. Expansion versus age $\mathbf{7 5}$ percent relative humidity

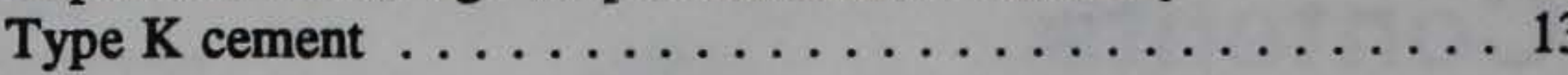

Figure 6. Expansion versus age 100 percent relative humidity

Type K cement . . . . . . . . . . . . . . . . . . 14

Figure 7. Strength versus age 50 percent relative humidity

Class $\mathrm{H}$ mixtures . . . . . . . . . . . . . . . 15

Figure 8. Strength versus age $\mathbf{7 5}$ percent relative humidity

Class $\mathrm{H}$ mixtures . . . . . . . . . . . . . . 16

Figure 9. Strength versus age 100 percent relative humidity

Class $\mathrm{H}$ mixtures $\ldots \ldots \ldots \ldots \ldots \ldots \ldots \ldots$

Figure 10. Strength versus age 50 percent relative humidity

Type $\mathrm{K}$ mixtures . . . . . . . . . . . . . . . . 18

Figure 11. Strength versus age $\mathbf{7 5}$ percent relative humidity

Type $\mathrm{K}$ mixtures

Figure 12. Strength versus age 100 percent relative humidity

Type K mixtures 


\section{Preface}

This work was performed for Sandia National Laboratories (SNL), supported by the U.S. Department of Energy, under contract DE-AC0476DP00789. The performing agency was the Concrete Technology Division (CTD), Structures Laboratory (SL), U.S. Army Engineer Waterways Experiment Station (WES), under SNL Document Number AA 2030. Dr. Lillian D. Wakeley, WES, was Principal Investigator. Dr. E. J. Nowak was Project Manager for SNL, Department 6121, of which Dr. Joe Tillerson is Manager.

Laboratory studies were accomplished in CTD during May through December, 1990, with direct guidance from Dr. Lillian D. Wakeley, Engineering Sciences Branch. The project plan was RPP 90-8 and RPP 90-08B. Dr. Toy S. Poole contributed to the planning of the project, analyzed the data, and wrote the report with assistance from Dr. Wakeley. Messrs. John Cook, Charles White, and Pete Burkes executed the technical work.

This project was accomplished under the general supervision of Mr. Bryant Mather, Director, SL; Mr. James T. Ballard, Assistant Director, SL; Mr. Kenneth L. Saucier, Chief, CTD. Dr. Wakeley was the principal investigator.

At the time of publication of this report, Director of WES was Dr. Robert W. Whalin. Commander was COL Leonard G. Hassell, EN. 


\section{Introduction}

The purpose of some of the research at the Waterways Experiment Station (WES) in support of materials development for Sandia National Laboratories (SNL) and the Waste Isolation Pilot Plant (WIPP) was to describe quantitatively how placing and early-age properties of candidate grouts and concretes are affected by temperature, humidity, and properties of component materials. Previous work had investigated the effect of changing cement and pozzolan sources on length-change and early strength development (Buck et al. 1983). Changing cement source was found to have some effect on early length change, but later-age length change tended to converge on a common value. Type $\mathrm{K}$ cement-based mixtures expanded more than Class $\mathrm{H}$ oil-well cement-based mixtures. Changing pozzolan source appeared to have a strong effect on expansion. Changes in w/c also appeared to be important.

The effects of temperature and relative humidity have not been systematically investigated. Previous work on expansive behavior reported numerous instances when expansion mechanisms apparently failed. These events were attributed to poor sealing of specimens soon after casting, which allowed them to dry and consequently shrink. Companion specimens stored in water or in fog expanded. Clearly moisture availability is important, but the effect has not been quantified. 


\section{Mixtures, Materials, and Methods}

In the work reported here, the length change and strength gain behavior of two expansive mixtures was investigated at several temperatures and relative humidities. One of the mixtures was a mortar equivalent of BCT-1-FF (Gulick and Wakeley 1989). This expansive grout has been the object of many previous studies of candidate sealing materials. The other mixture was based on a Type K expansive cement. Experimental conditions were selected to cover the probable range of temperatures and relative humidities to be expected in placing and early curing of concrete at the WIPP. Neither mixture contained sodium chloride as a component. Mixing proportions had been selected during a period of research on freshwater grouts, the use of which was anticipated in non-halide rock units at the WIPP.

Materials were as follows.

\begin{tabular}{||l|l|l||}
\hline Material & $\begin{array}{l}\text { Applicable } \\
\text { Specification }\end{array}$ & CTD Ref. Number \\
\hline \hline TYpe K expansive cement & ASTM C 845 & WIPP-1 RC-1 \\
\hline Class H oil-well cement & API 210 & WIPP-1 RC-2 \\
\hline Class C fly ash & ASTM C 618 & LMK-4 AD-4 \\
\hline High-range water reducer (HRWR) & ASTM C 494 & \\
\hline Standard graded sand & ASTM C 778 & Lab stock \\
\hline Deionized water & ASTM D 1193 & Lab stock \\
\hline Plaster & ASTM C 28 & WIPP-1 RC-3 \\
\hline
\end{tabular}

The Type $\mathrm{K}$ mixture contained fly ash ( 35 percent by absolute volume of cement), fine aggregate (sand), water, and a high-range water reducer (HRWR). The ratio of water to cement + fly ash (w/cfa) was 0.30 by mass. The ratio of cement + fly ash to sand was 0.5 . The HRWR dosage was adjusted to give the mortar a flow of $110 \pm 5$, according to ASTM C 109-90 (ASTM 1990a). The BCT-1-FF-like mixture was proportioned like the 
Type $\mathrm{K}$ mixture except Class $\mathrm{H}$ oil-well cement and plaster (10 percent by mass of cement) were substituted for the Type $\mathrm{K}$ cement.

Restrained-expansion mortar bars ( 2 by 2 by 10 in.) were fabricated and measured according to ASTM C 806-87 through paragraph 11.3 (ASTM 1990b). Mortars were mixed and bars fabricated at $23^{\circ} \mathrm{C}$ and stored in molds in a moist cabinet for $\mathbf{2 4}$ hours at the same temperature. They were then demolded and placed in the experimental temperature-humidity condition for 24 hours. Initial gage length was recorded at the end of this 48 -hour period, so initial change in length was first measured at 3 days. Subsequent length-change measurements were taken daily, usually, to 7 days, and then weekly until the bars appeared to have reached length stability. Each datum in Tables 1 and 2 represents the mean length change of two bars, which were fabricated from the same batch. Some mixtures were duplicated but time and equipment constraints prevented full duplication of tests (total number of specimens: 60 ).

Mortar cubes (2-in.) were fabricated according to ASTM C 109 from the same batches from which the restrained bars were made. Cubes from all mixtures were tested for compressive strength at $3,7,14$, and 21 days. Data from later ages also were collected when bar measurements were extended beyond 21 days. Two cubes were broken per mixture for most test ages shown in Tables 3 and 4 (total number of specimens: 330 ).

Temperature conditions were $23{ }^{\circ} \mathrm{C}, 30^{\circ} \mathrm{C}$, and $38^{\circ} \mathrm{C}$. Some mixtures were also tested at $50^{\circ} \mathrm{C}$. Relative humidity $(\mathrm{RH})$ conditions were 50 percent, 75 percent, and 100 percent. A moist cabinet conforming to ASTM C 511 (ASTM 1990c) was used for the $23^{\circ} \mathrm{C}, 100$ percent RH condition. Two variably-adjustable environmental cabinets (Tenny Model 14, Standard International Systems Model RB/5) were used for the other conditions. Relative humidity conditions were verified by measurement with a wet-dry bulb thermometer. 
Table 1

Length-Change Data, Class H Cement Mixtures

\begin{tabular}{|c|c|c|c|c|}
\hline Age (days) & $23^{\circ} \mathrm{C}$ & $30^{\circ} \mathrm{C}$ & $38^{\circ} \mathrm{C}$ & $50^{\circ} \mathrm{C}$ \\
\hline \multicolumn{5}{|c|}{$100 \%$ Relative Humidity } \\
\hline 2 & 0.015 & & & \\
\hline 3 & 0.020 & 0.005 & -0.003 & -0.017 \\
\hline 4 & 0.027 & 0.006 & -0.018 & -0.014 \\
\hline 5 & 0.037 & 0.002 & & \\
\hline 7 & 0.046 & -0.015 & -.018 & -0.029 \\
\hline 14 & 0.064 & -0.005 & -.017 & -0.018 \\
\hline 21 & 0.065 & -0.004 & -.017 & -0.016 \\
\hline 28 & 0.067 & & -.014 & -0.015 \\
\hline 37 & 0.066 & & -.016 & -0.018 \\
\hline \multicolumn{5}{|c|}{ 75\% Relative Humidity } \\
\hline 3 & -0.001 & 0.002 & -0.061 & \\
\hline 4 & -0.011 & -0.004 & -0.022 & \\
\hline 5 & -0.007 & -0.008 & & \\
\hline 6 & -.008 & -0.012 & & \\
\hline 7 & -.0184 & -0.016 & -0.030 & \\
\hline 14 & -0.026 & -0.023 & -0.034 & \\
\hline 21 & -0.030 & -0.026 & -0.037 & \\
\hline 28 & & & -0.035 & \\
\hline 37 & & & -0.034 & \\
\hline \multicolumn{5}{|c|}{$50 \%$ Relative Humidity } \\
\hline 3 & -0.005 & -0.010 & -0.020 & \\
\hline 4 & -0.015 & -0.022 & -0.032 & \\
\hline 5 & -0.019 & -0.030 & -0.037 & \\
\hline 6 & -0.030 & -0.039 & & \\
\hline 7 & -0.035 & -0.046 & -0.046 & \\
\hline 14 & -0.053 & -0.054 & -0.051 & \\
\hline 21 & -0.052 & -0.057 & -0.050 & \\
\hline 28 & & & -0.048 & \\
\hline 37 & & & -0.048 & \\
\hline
\end{tabular}




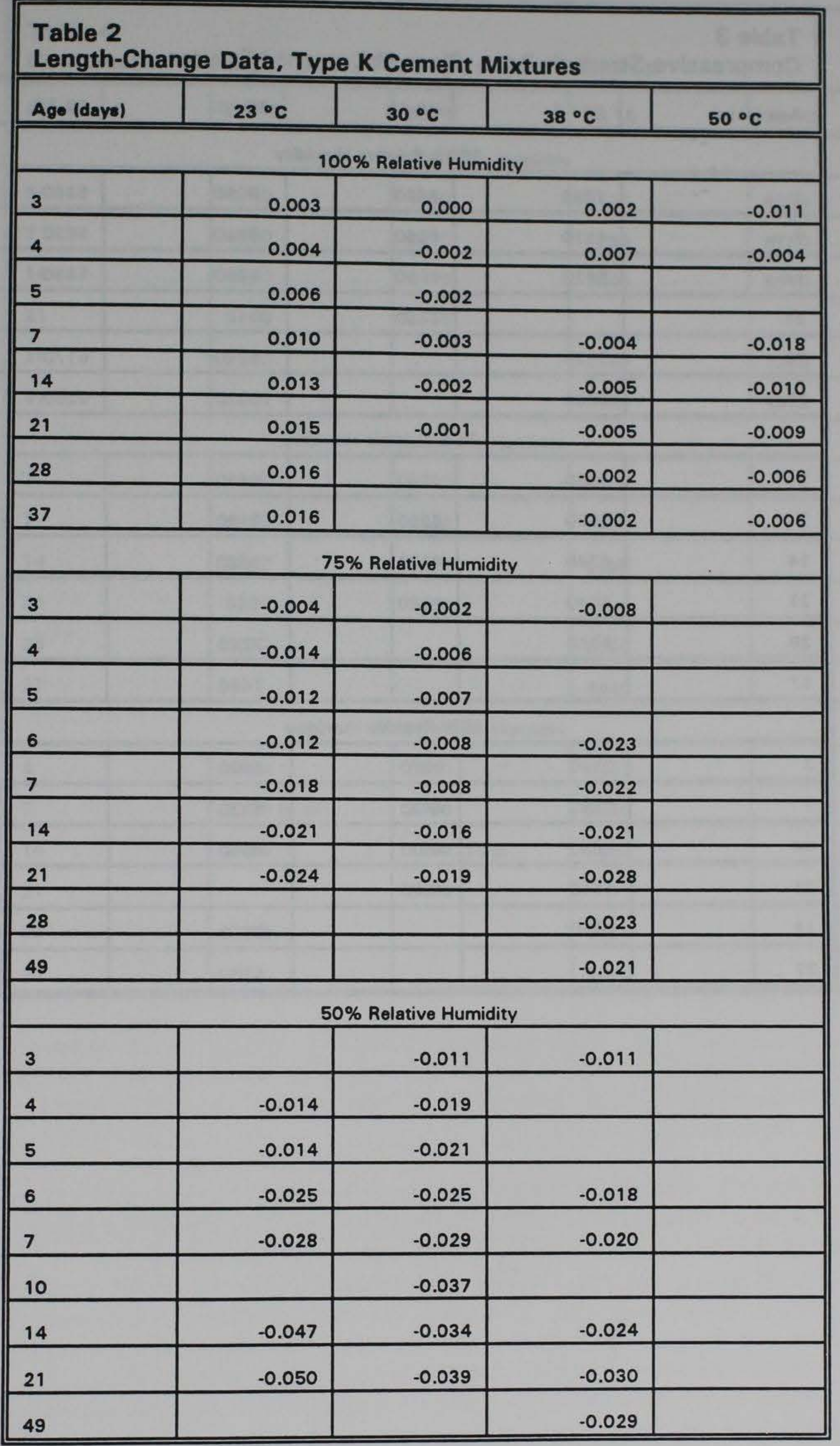




\begin{tabular}{|c|c|c|c|c|}
\hline \multicolumn{5}{|c|}{$\begin{array}{l}\text { Table } 3 \\
\text { Compressive-Strength Data, Class H Cement Mixtures }\end{array}$} \\
\hline Age (daye) & $23^{\circ} \mathrm{C}$ & $30^{\circ} \mathrm{C}$ & $38^{\circ} \mathrm{C}$ & $50^{\circ} \mathrm{C}$ \\
\hline \multicolumn{5}{|c|}{$100 \%$ Relative Humidity } \\
\hline 3 & 2890 & 3620 & 6020 & 5380 \\
\hline 7 & 4310 & 6260 & 7810 & 5630 \\
\hline 14 & 5920 & 6900 & 9230 & 5860 \\
\hline 21 & & 7730 & & \\
\hline 28 & 7320 & & 8810 & 6170 \\
\hline 37 & 8000 & & 10500 & 6250 \\
\hline \multicolumn{5}{|c|}{ 75\% Relative Humidity } \\
\hline 3 & 3250 & 4930 & 5440 & \\
\hline 7 & 3990 & 6220 & 7120 & \\
\hline 14 & 4740 & 6150 & 7260 & \\
\hline 21 & 5040 & 6080 & & \\
\hline 28 & 5320 & & 7810 & \\
\hline 37 & & & 7480 & \\
\hline \multicolumn{5}{|c|}{$50 \%$ Relative Humidity } \\
\hline 3 & 3190 & 3670 & 3800 & \\
\hline 7 & 3480 & 4480 & 4330 & \\
\hline 14 & 4040 & 4400 & 4800 & \\
\hline 21 & 4140 & 4560 & & \\
\hline 28 & 4510 & & 4830 & \\
\hline 37 & & & 4380 & \\
\hline
\end{tabular}




\section{Table 4}

Compressive-Strength Data, Type K Cement Mixtures

\begin{tabular}{|c|c|c|c|c|}
\hline Age (days) & $23^{\circ} \mathrm{C}$ & $30^{\circ} \mathrm{C}$ & $38^{\circ} \mathrm{C}$ & $50^{\circ} \mathrm{C}$ \\
\hline \multicolumn{5}{|c|}{$100 \%$ Relative Humidity } \\
\hline 3 & 4740 & 4930 & 6310 & 6980 \\
\hline 7 & 6000 & 5910 & 8260 & 6780 \\
\hline 14 & 6770 & 6470 & 8240 & 6910 \\
\hline 21 & 8760 & 7000 & & \\
\hline 28 & 9760 & & 8740 & 7760 \\
\hline 37 & & & 9450 & 7380 \\
\hline \multicolumn{5}{|c|}{ 75\% Relative Humidity } \\
\hline 3 & 4300 & 5390 & 5950 & \\
\hline 7 & 4950 & 6140 & 7370 & \\
\hline 14 & 5360 & 6490 & 8290 & \\
\hline 21 & 6280 & 7110 & & \\
\hline 28 & 6070 & & 9290 & \\
\hline 37 & & & 8440 & \\
\hline \multicolumn{5}{|c|}{$50 \%$ Relative Humidity } \\
\hline 3 & 4730 & 5910 & 6430 & \\
\hline 7 & $5360(8 d)$ & 6760 & 6890 & \\
\hline 14 & 5440 & $7000(15 d)$ & 7220 & \\
\hline 21 & & 6930 & & \\
\hline 28 & 6240 & & 6980 & \\
\hline 37 & & & 6960 & \\
\hline
\end{tabular}




\section{Results}

\section{Results}

Data for length change and strength are summarized in Tables 1 through 4. Time-dependent length-change patterns are illustrated in Figures 1 through 6. Time-dependent strength-change patterns are illustrated in Figures 7 through 12.

Length change was always negative under conditions of 50 percent and 75 percent RH (Figures 1, 2 and 4, 5), regardless of temperature. The only positive length changes occurred at 100 percent $\mathrm{RH}$. The positive change at $23{ }^{\circ} \mathrm{C}, 100$ percent $\mathrm{RH}$ was unambiguous, but at higher temperatures under the same RH conditions, positive length changes occurred but were transient over days 3 through 5 , and then became negative at later ages (see Figures 3 and 6). These negative values did not appear to be a result of drying due to accidental loss of RH in the storage cabinets because values were stable with time. The data may show even a slight tendency towards reversing the apparent shrinkage at later ages. One difference between the 100 percent RH condition at $23{ }^{\circ} \mathrm{C}$ and the 75 percent and 50 percent $\mathrm{RH}$ conditions was the presence of liquid water in the 100 percent RH condition. Specimens stored over water in sealed containers may have liquid water condense on their surfaces. If the storage temperature cycles, this will be more likely.

At the $23{ }^{\circ} \mathrm{C}$ and 100 percent relative humidity, ultimate expansion was greater in the Class H-based mixture ( 0.065 percent) than in the Type K-based mixture $(0.020$ percent). Length change stabilized by 14 days under these conditions in both mixtures.

Strength development responded to temperature and relative humidity about as expected from behavior of non-expansive systems, i.e. low relative humidity retards strength gain, while mildly elevated temperatures accelerate strength gain. The Type-K mixtures were generally stronger than the Class- $\mathrm{H}$ mixtures at equivalent ages. Low relative humidity caused strength development to cease, and, in the case of $38^{\circ} \mathrm{C}$ storage, strength tended to be lower at the last test age ( 37 days) than at earlier ages. These apparent changes in strength are small relative to the variation among cubes at each test age, suggesting that they are a coincidental consequence of testing precision. Strength gain at $50^{\circ} \mathrm{C}$ was severely retarded relative to gain at the other test temperatures. 


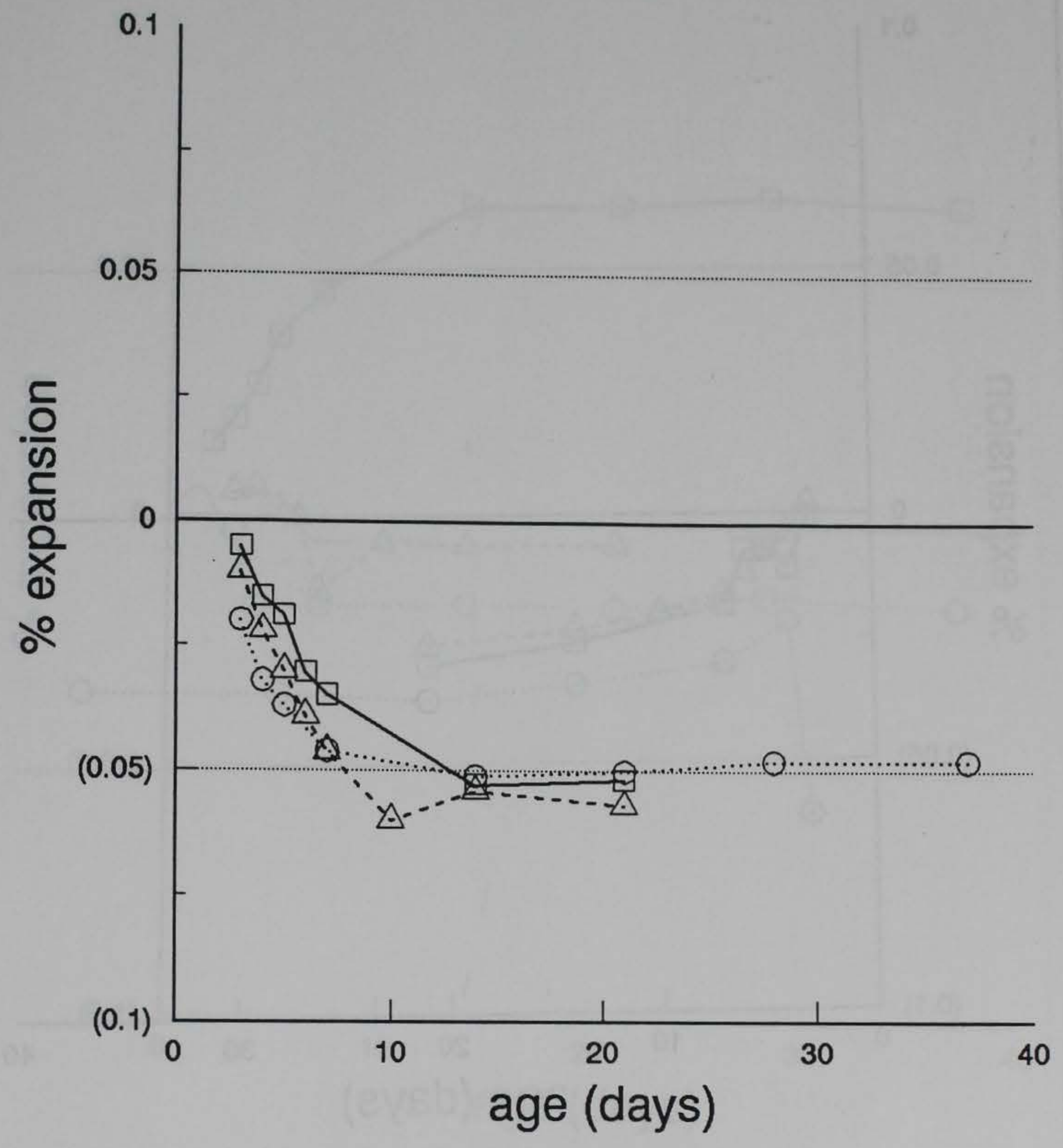

$23 \operatorname{deg} C \mathbf{3 0} \operatorname{deg} C 38 \operatorname{deg} C$

$\square \quad--\AA-. \cdots . . .$.

Figure 1. Expansion versus age 50 percent relative humidity Class $\mathrm{H}$ cement 


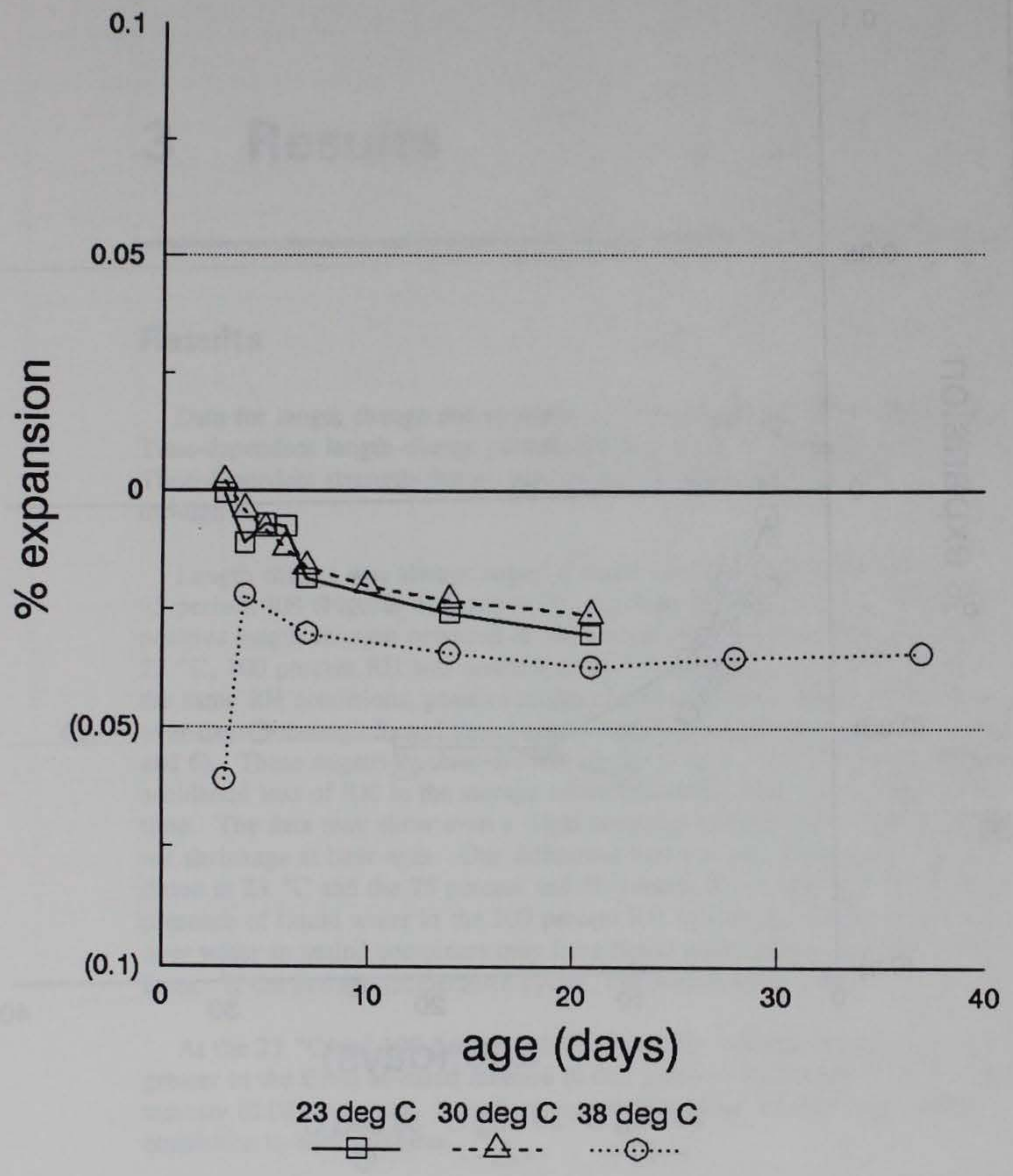

Figure 2. Expansion versus age $\mathbf{7 5}$ percent relative humidity Class $\mathrm{H}$ cement 


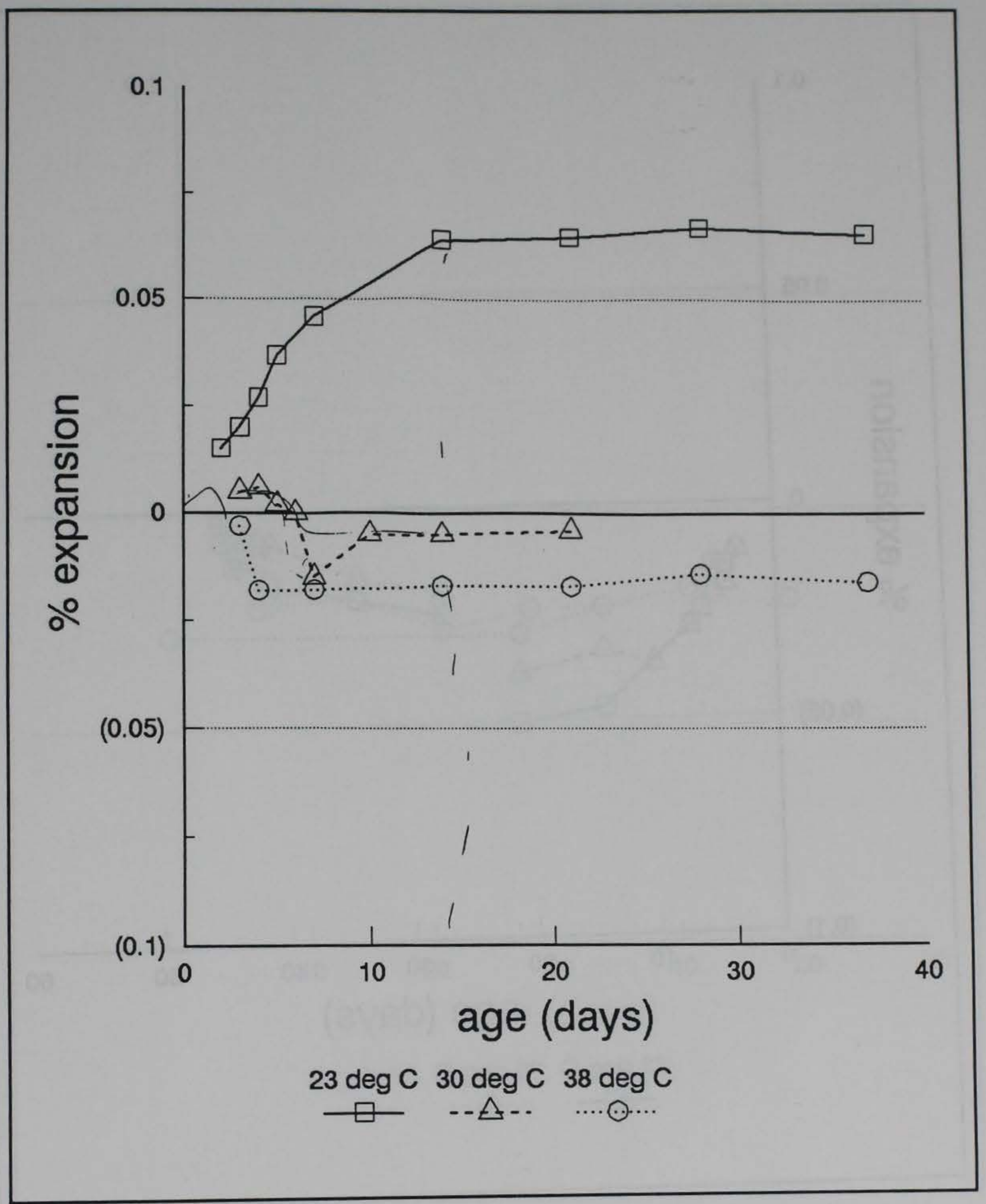

Figure 3. Expansion versus age 100 percent relative humidity Class $\mathrm{H}$ cement 


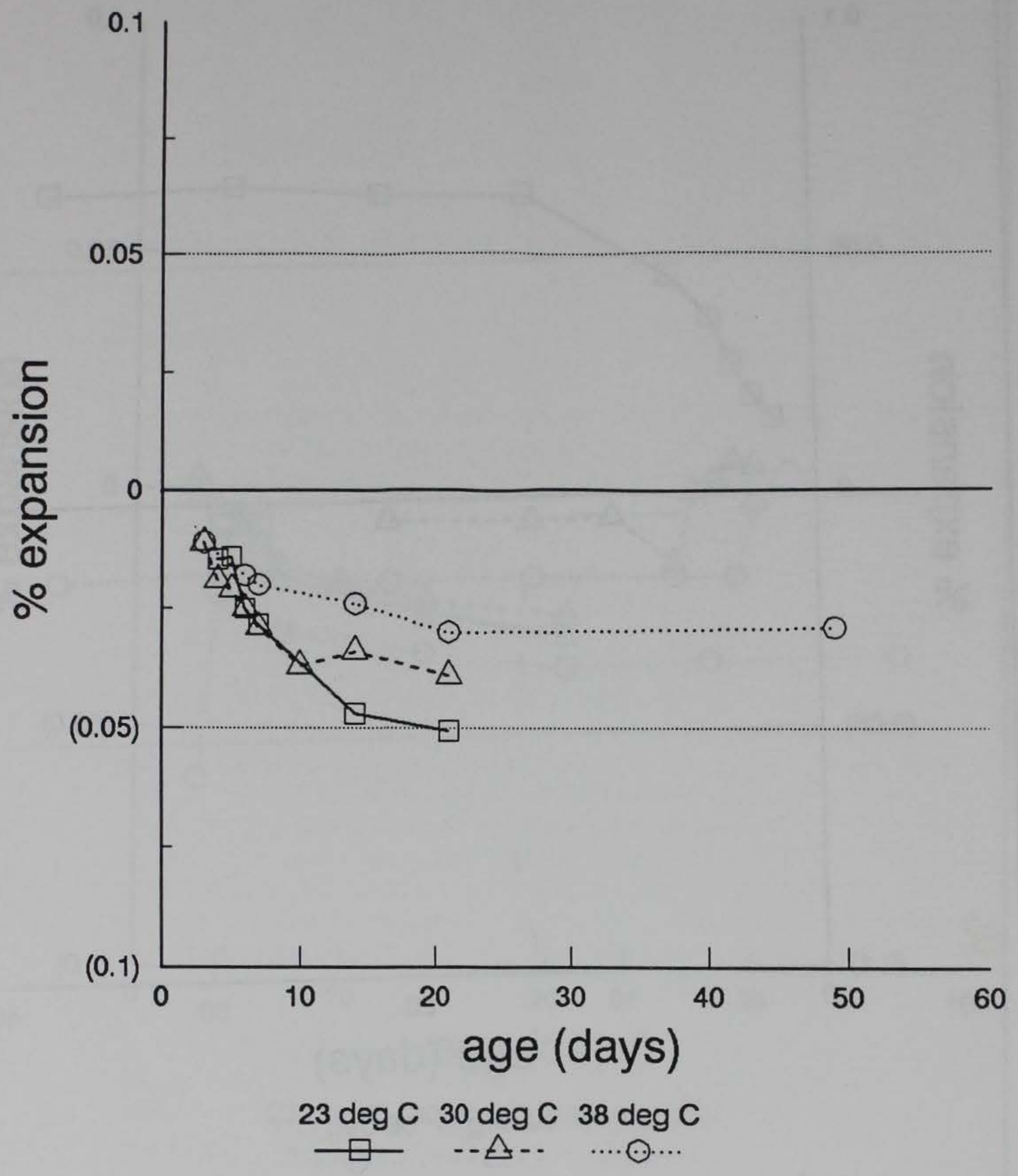

Figure 4. Expansion versus age 50 percent relative humidity Type $\mathrm{K}$ cement 


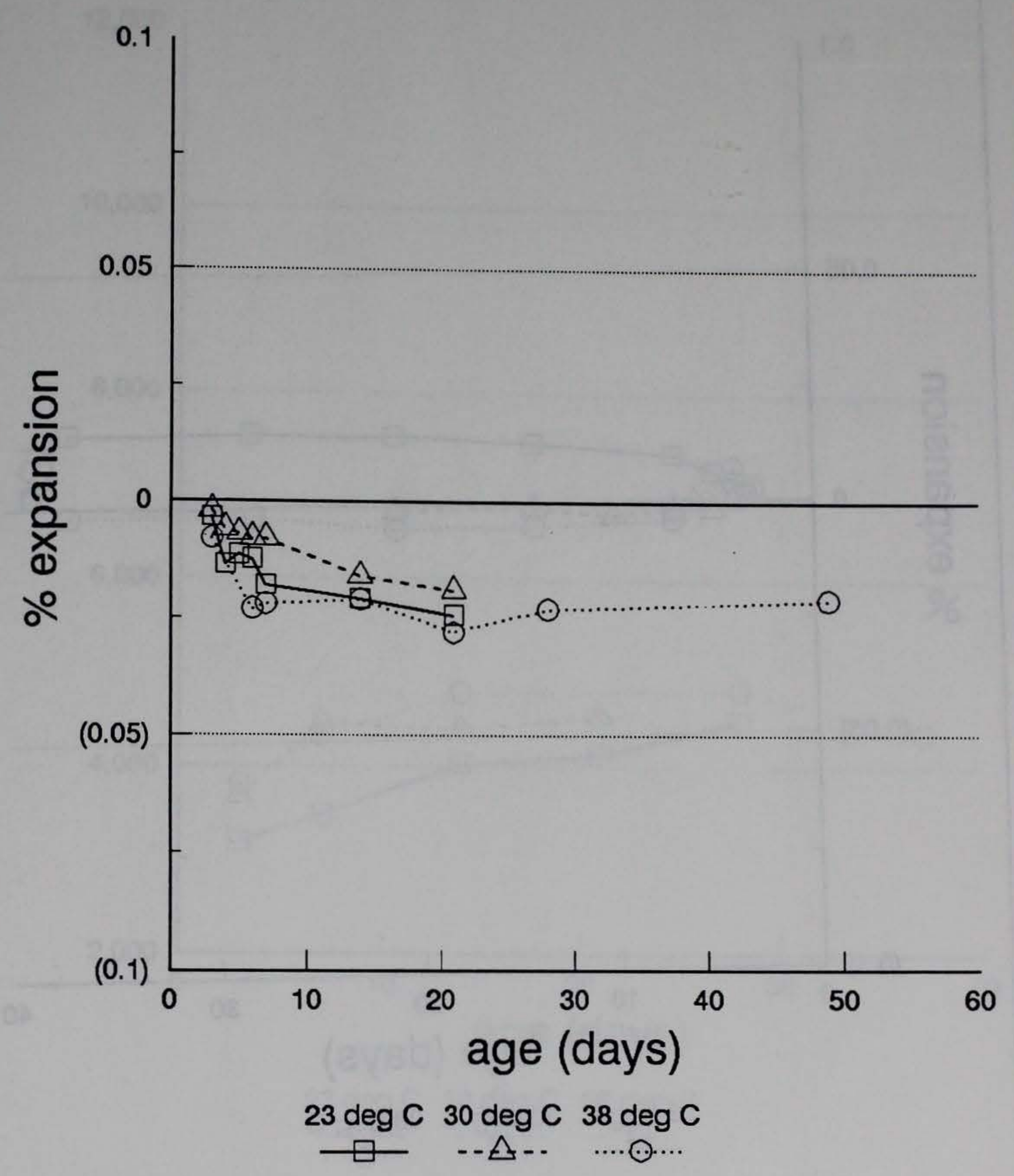

Figure 5. Expansion versus age 75 percent relative humidity Type $\mathrm{K}$ cement 


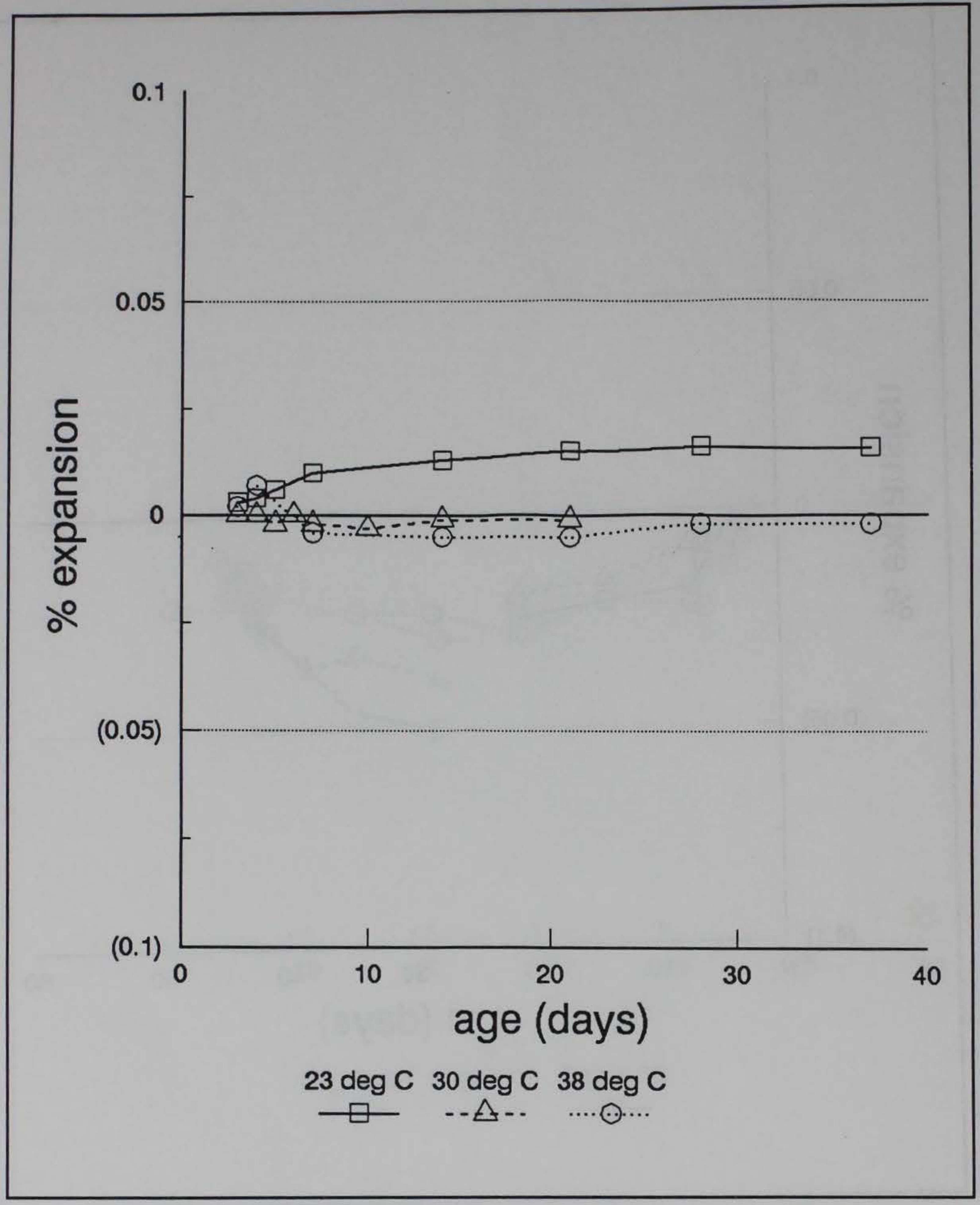

Figure 6. Expansion versus age 100 percent relative humidity Type $K$ cement 


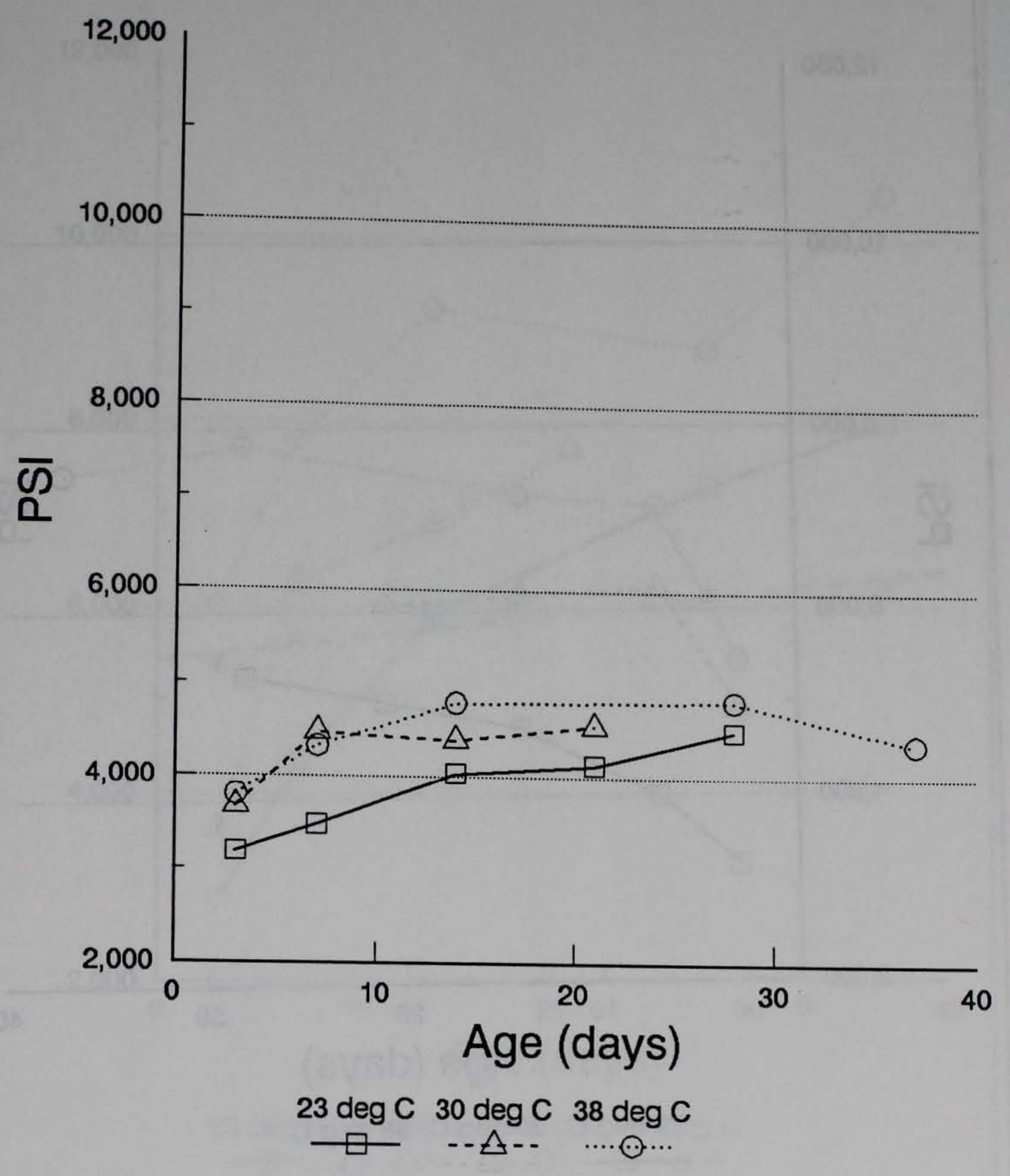

Figure 7. Strength versus age 50 percent relative humidity Class $\mathrm{H}$ mixtures 


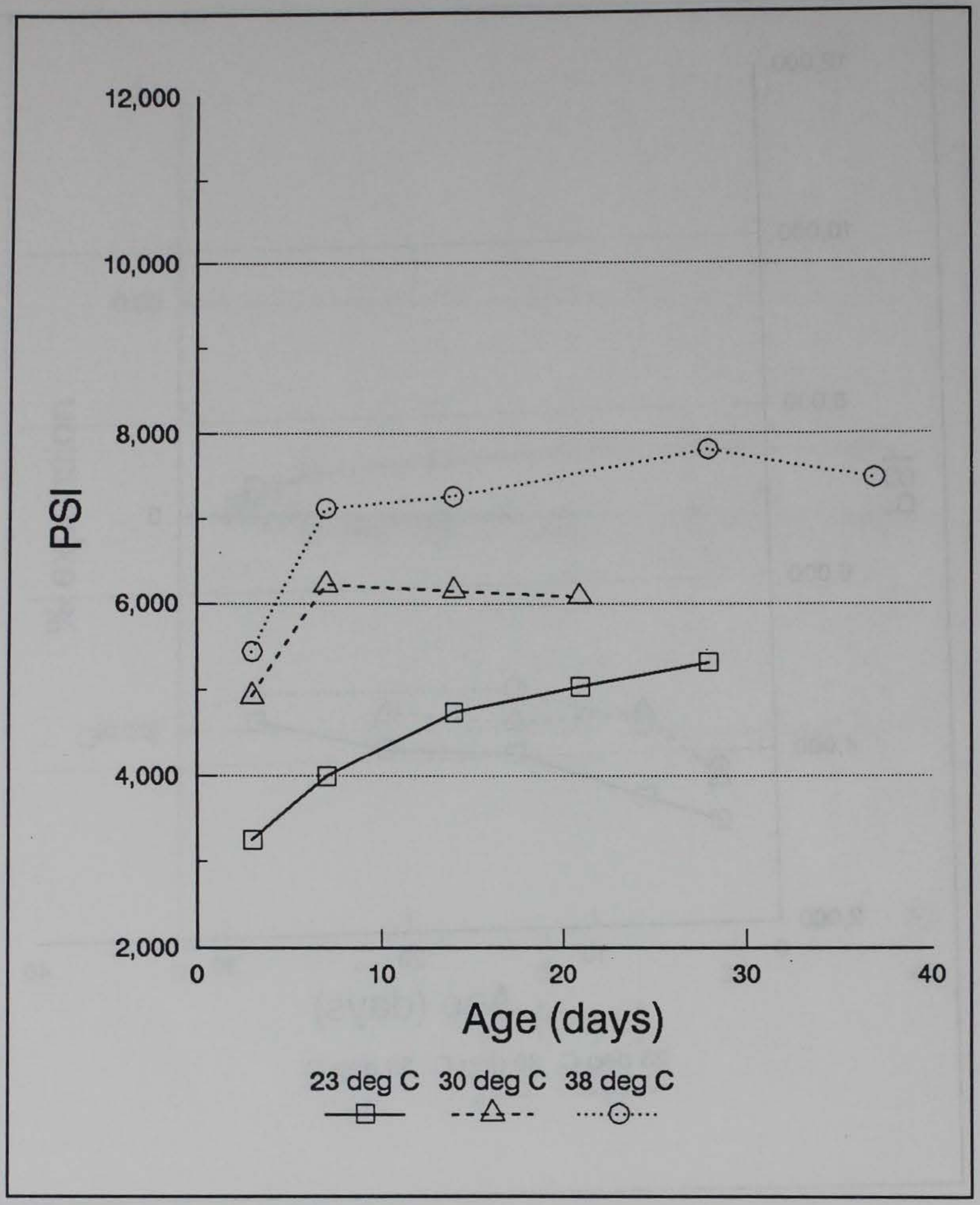

Figure 8. Strength versus age 75 percent relative humidity Class $\mathrm{H}$ mixtures 


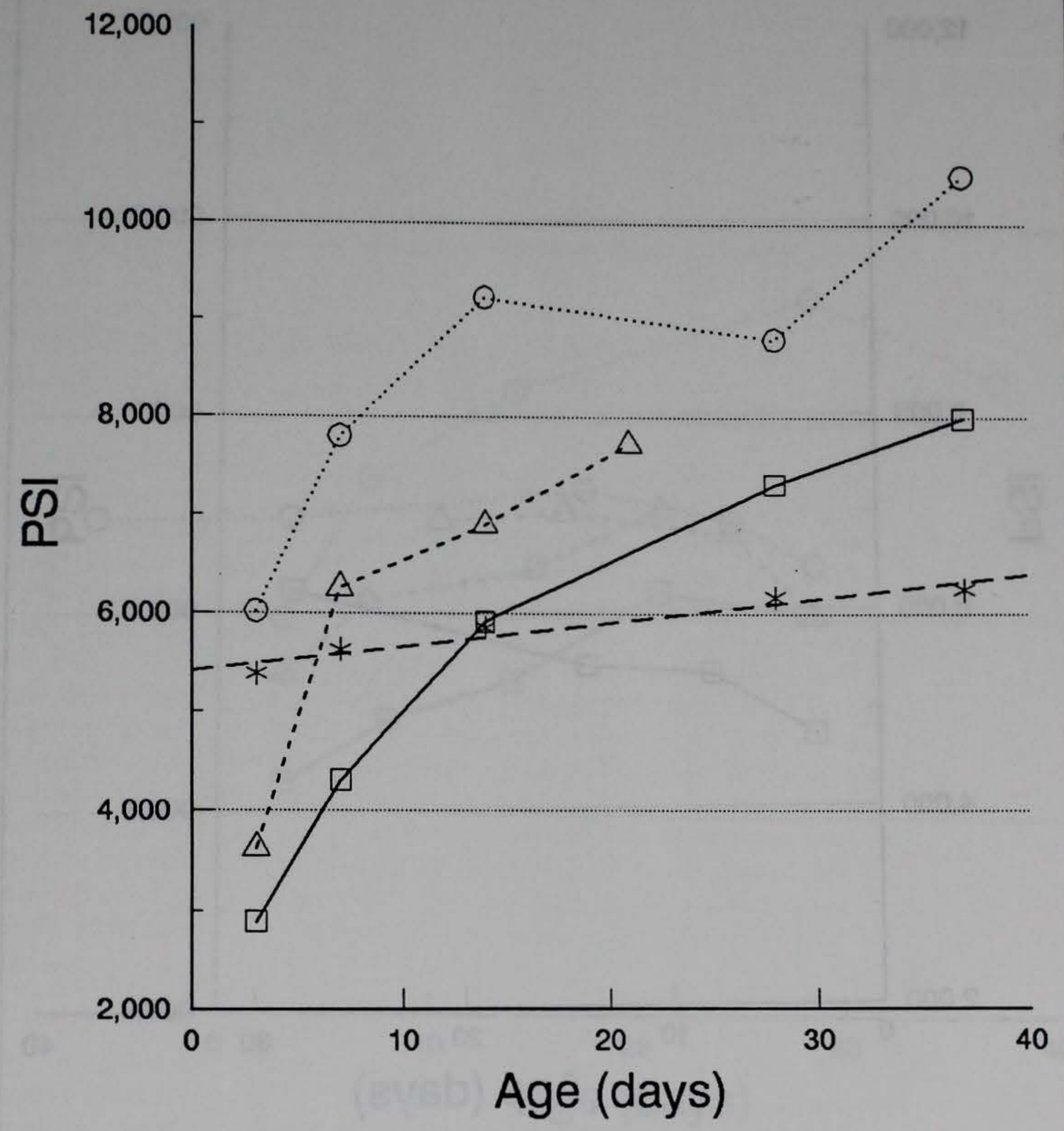

$23 \operatorname{deg} C 30 \operatorname{deg} C 38 \mathrm{deg} C 50 \mathrm{deg} C$

$\square-\cdots-\cdots . \cdots \quad-*-$

Figure 9. Strength versus age 100 percent relative humidity Class $\mathrm{H}$ mixtures 


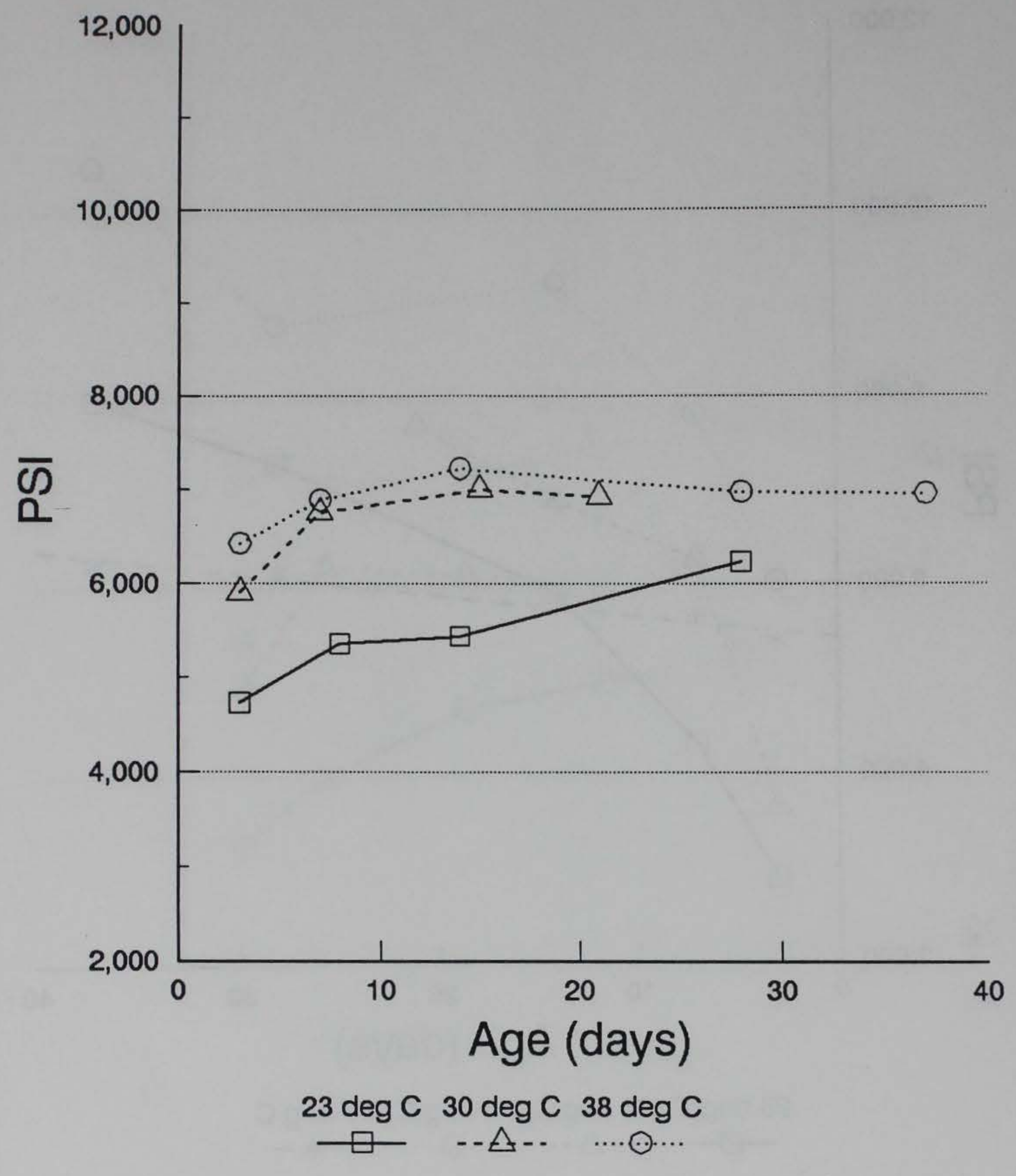

Figure 10. Strength versus age 50 percent relative humidity Type $K$ mixtures 


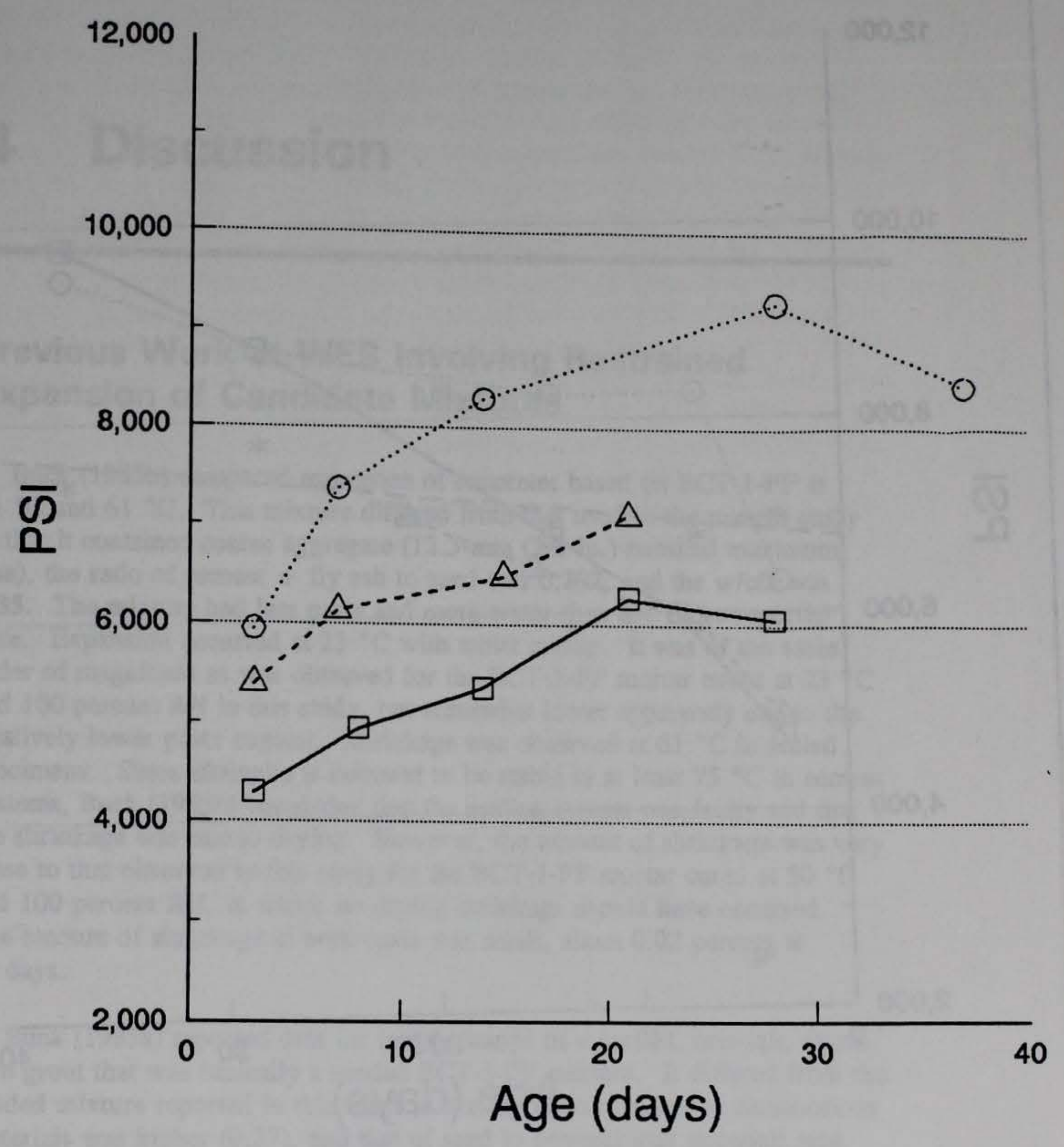

$23 \mathrm{deg} C 30 \mathrm{deg} C 38 \mathrm{deg} C$

$\square \quad-\triangle-. \quad \cdots \odot \cdots$

Figure 11. Strength versus age 75 percent relative humidity Type $K$ mixtures 


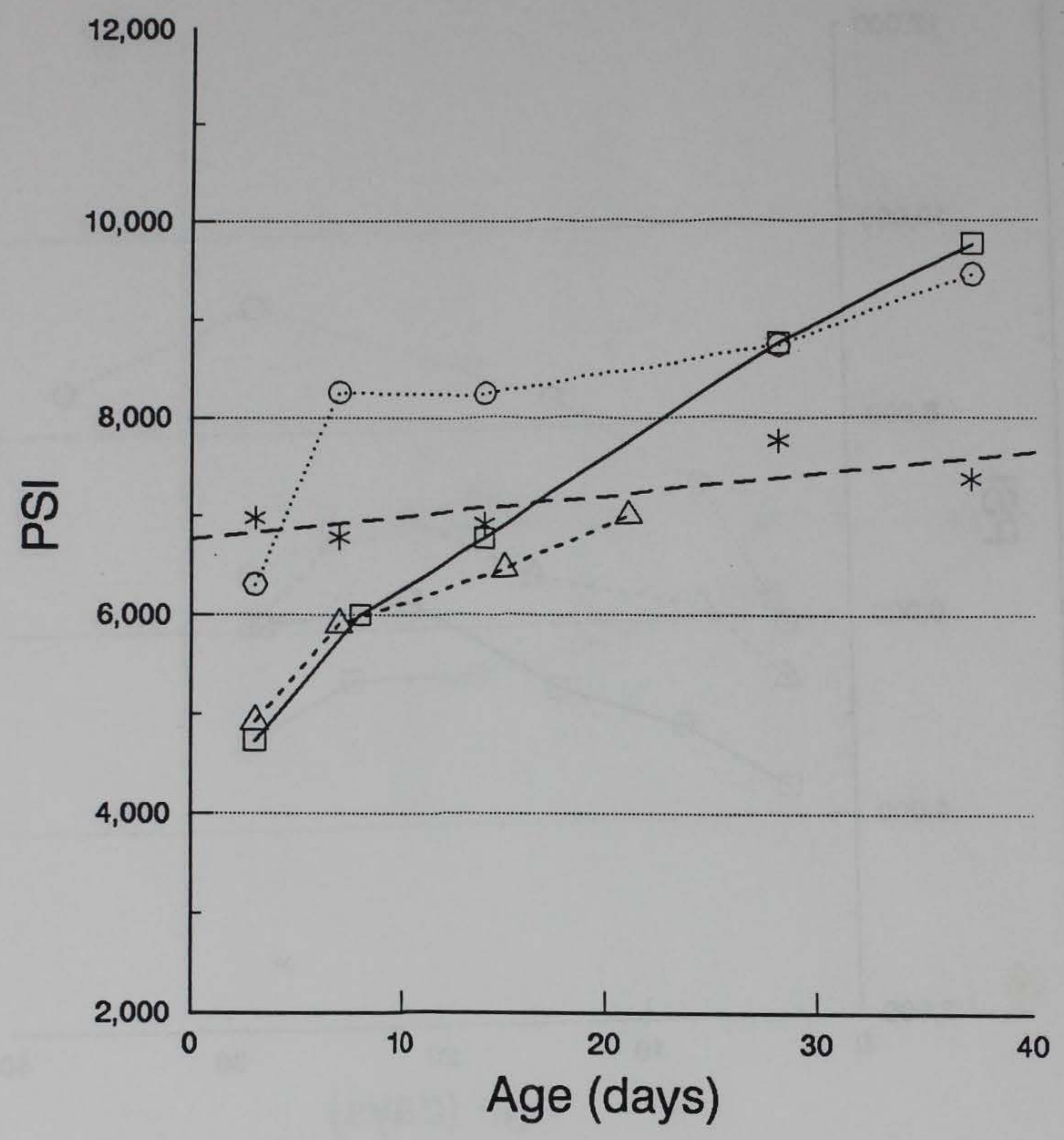

$23 \operatorname{deg} C 30 \operatorname{deg} C 38 \operatorname{deg} C 50 \operatorname{deg} C$

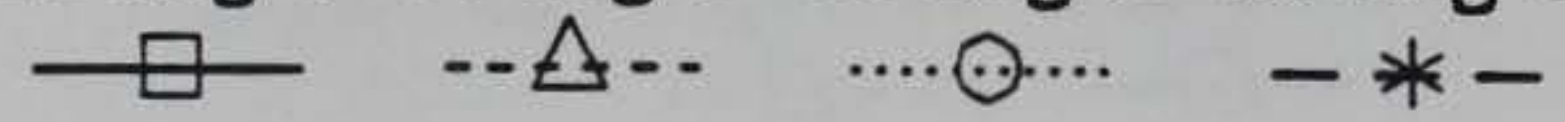

Figure 12. Strength versus age 100 percent relative humidity Type $K$ mixtures 


\section{Discussion}

\section{Previous Work at WES Involving Restrained Expansion of Candidate Mixtures}

Buck (1985b) compared expansion of concretes based on BCT-1-FF at $23^{\circ} \mathrm{C}$ and $61^{\circ} \mathrm{C}$. This mixture differed from that used in the present study in that it contained coarse aggregate (12.5-mm (1/2-in.) nominal maximum size), the ratio of cement + fly ash to sand was 0.292 , and the w/cfa was 0.35. The mixture had less paste and more water than had those reported here. Expansion occurred at $23^{\circ} \mathrm{C}$ with moist curing. It was of the same order of magnitude as was observed for the BCT-1-FF mortar cured at $23{ }^{\circ} \mathrm{C}$ and 100 percent $\mathrm{RH}$ in this study, but somewhat lower apparently due to the relatively lower paste content. Shrinkage was observed at $61{ }^{\circ} \mathrm{C}$ in sealed specimens. Since ettringite is believed to be stable to at least $75^{\circ} \mathrm{C}$ in cement systems, Buck (1985b) concluded that the sealing system was faulty and that the shrinkage was due to drying. However, the amount of shrinkage was very close to that observed in this study for the BCT-1-FF mortar cured at $50{ }^{\circ} \mathrm{C}$ and 100 percent $\mathrm{RH}$, in which no drying shrinkage should have occurred. The amount of shrinkage in both cases was small, about 0.02 percent at 28 days.

Buck (1985a) reported data for length change of a sanded, non-salt, expansive grout that was basically a sanded BCT-1-FF mixture. It differed from the sanded mixture reported in this work in that the ratio of water to cementitious materials was higher (0.37), and that of sand to cementitious materials was considerably lower $(0.67)$, so there was relatively more paste volume. He compared length change at $23{ }^{\circ} \mathrm{C}$ and $30^{\circ} \mathrm{C}$ in moist storage with that resulting from storage of wax-sealed specimens in air. Expansion at $23^{\circ} \mathrm{C}$ in moist storage was somewhat higher than in the present study at equivalent ages, due apparently to the higher relative paste volume. The specimens stored at $30^{\circ} \mathrm{C}$ also expanded, then lost some expansion (relative negative length change), then expanded again at about 56 days. Specimens stored at $30^{\circ} \mathrm{C}$, but wax sealed and in air, expanded early but then lost the expansion at later ages (one eventually showed negative length changes, the other showed a relative reduction in expansion, but never reached zero). Buck attributed the loss of the early expansion in the waxed bars to drying, but recommended further study to verify this. 
Data for expansion of unsanded grouts representing several combinations of materials were reported by Buck et al. (1983). Specimens were stored in saturated lime water at $23^{\circ} \mathrm{C}$. Expansion of the BCT-1-FF mixture was very slow to develop, showing negative values at 7 days, but expansions at 28 days were comparable to those reported in the present study. Changing the source of the fly ash resulted in a several fold increase in expansion, probably attributable to differences in chemical composition, or particle size, or both.

Effects of curing temperature and water availability (inundation versus wrapped and bagged) was reported by Gulick, Boa, and Buck (1980). In comparisons of paste specimens cured at $53{ }^{\circ} \mathrm{C}$, inundated specimens expanded 0.05 percent at 56 days (somewhat less expansion than observed at $23^{\circ} \mathrm{C}$ in the present study), while wrapped and bagged specimens showed negative length change of -0.03 percent. It was concluded that drying shrinkage through a faulty sealing system was responsible for the latter. There was also a temperature effect among inundated specimens. Specimens stored at $23^{\circ} \mathrm{C}$ expanded more at 28 days $(0.020$ percent $)$ than specimens stored at $53{ }^{\circ} \mathrm{C}(0.010$ percent); but by 100 days, expansion in both groups was about the same ( 0.055 percent).

\section{Probable Causes of Observed Expansion}

It was expected that expansion at elevated temperatures and 100 percent RH would occur. The failure of such behavior to occur had been attributed to imperfect control of curing conditions. In most of these cases, the conditions for 100 percent RH were established by wrapping the bars in a plastic membrane and then double bagging with plastic bags with storage in laboratory air. There were generally no data reported in support of the drying-shrinkage hypothesis. Rather, it was taken as a plausible explanation for the apparently deviant behavior. This hypothesis is plausible for long-term storage conditions, because plastic does allow some transmission of moisture. However, this type of triple-layer sealing system should provide conditions close to 100 percent $\mathrm{RH}$ for a period of a month or so, such as those of the present study. Most of the suspect data from previous work reported no expansion even at very early ages. The results obtained in the current work, in which no drying was allowed because of the 100 percent $\mathrm{RH}$ condition, suggest that some other mechanism may be contributing to this phenomenon.

A review of the literature on the mechanisms of expansion in systems that rely on formation of ettringite may be enlightening. The exact mechanism by which expansion accompanies formation of ettringite is not universally agreed upon. Expansion appears to accompany formation of ettringite, but formation of ettringite does not always result in expansion. There are said to be at least two schools of thought on the mechanism by which formation of ettringite causes expansion. These were reviewed by Cohen (1983a). These are not necessarily mutually exclusive, nor are they necessarily inclusive of all possibilities, as was discussed by Mather (1984). 
One hypothesis is that expansion occurs when very small ettringite crystals form. These have a high surface area, resembling a gel. Under this hypothesis, it is believed that the formation of the ettringite per se does not cause expansion, beeause the total volume of the reaction products is less than the total volume of the reactants. But, it is hypothesized that, this gel swells by imbibing water. This hypothesis would require that water be taken into the system. According to this mechanism, no swelling occurs if ettringite crystals are large or if water is not available. This hypothesis is often called the swelling hypothesis.

According to the other hypothesis, expansion occurs because of the growth of ettringite crystals on the surface of calcium aluminates. Solid sulfates are hypothesized to dissolve and sulfate ions are said to diffuse towards the aluminate sites; this is a through-solution reaction. The total volume of the reaction products is slightly smaller that the total volume of the reactants (including water), so linear growth of a crystal in a rigid matrix is hypothesized to cause expansion not by increasing the total volume of solid in the system but rather by leaving empty space formally occupied by water. This hypothesis is often called the crystal growth hypothesis.

It is most likely that when there is expansion of concrete, mortar, or grout resulting from a chemical reaction between sulfate ion in solution and chemically active aluminates in portland cement or expansive cement, the expansion is caused by topochemical, in situ, sulfation of the aluminate (Mather 1984). This concept assumes that crystal growth from solution never results in any force being exerted on the surroundings--a bottle containing a supersaturated solution is not broken by letting evaporation remove solvent so that crystals precipitate from the solution.

Odler and Gasser (1988) performed a detailed investigation into the mechanism of sulfate-based expansion in a portland-cement system. They found that the amount of expansion depended to some degree on externally derived water. There was enough water in the mixture to give some expansion in their sealed samples, but storage in water-saturated air resulted in more expansion, and storage in immersed conditions resulted in even more expansion. Their interpretation of these results was that at least some of the expansion must be due to crystal growth, since no water uptake was required for some expansion to occur. However, the enhanced expansion when water was taken up was viewed as evidence for a swelling component to the total expansion. Independent evidence for the latter was obtained by fabrication of pastes made from ettringite and tricalcium silicate $\left(\mathrm{C}_{3} \mathrm{~S}\right.$, a component of portland cement) which expanded when immersed, but did not when cured in saturated air.

Negro and Bachiorrini (1982) examined the effect of temperature on ettringite-based expansion. Their temperature range was $22^{\circ} \mathrm{C}$ to $60^{\circ} \mathrm{C}$. Early expansion generally increased with temperature, but this trend was less apparent at the higher temperatures. Also, the higher temperature conditions resulted in all expansion being depleted by about 3 days, while expansion in lower temperature conditions continued to about 7 days. SEM work indicated that the differences in the size of the ettringite crystals under different 
experimental conditions correlated with the observed expansion phenomena. They interpreted their results in the context of the swelling hypothesis.

Although the temperatures are different, it suggests that temperature could accelerate the expansive reaction to the point that it is largely dissipated by the age of the first length-change calculation. In extreme cases, a reaction that normally causes expansion may fail to do so if it approaches equilibrium before a rigid hydrated cement matrix is established. That is, if the ettringiteforming reaction is accelerated more than the strength-gain process, much of the desired expansion due to ettringite formation will be lost, since it takes place before the concrete is strong enough to expand due to internal volume change. This leaves the empty space previously occupied by the sulfate solution.

Panchenko (1990) investigated the effect on expansion of mortars by adding calcium hydroxide. Addition of lime resulted in increased expansion. The purpose of his work was to find a way to engineer levels of expansion, and Panchenko concluded that control of the addition of lime could do this. However, his results may have some importance in understanding expansion in systems containing fly ash. Because lime is consumed by reaction with a pozzolan such as fly ash, plausibly the amount of uncombined lime in blends of fly ash and portland cement varies with the relative amount of the pozzolan and the degree of hydration. This may explain some of the differences observed in expansion among mixtures containing different fly ashes. However, in a system with 65 percent portland cement and 35 percent fly ash there should be sufficient, available calcium to keep the pore fluid saturated and to produce CSH from all the silica in the cement and the fly ash and maintain a saturated $\mathrm{Ca}(\mathrm{OH})_{2}$ solution in the pore fluid permanently.

In a discussion of the effects of water-cement ratio (w/c) on cement hydration, Philleo (1983) expressed concern over the effects of self-desiccation in low w/c systems. His principal concern was over the differences in strength that would be developed when low w/c specimens are cured in water, compared with the strength that would develop when additional water is not available. Perhaps a similar concern should apply to developing expansive systems. This problem has been encountered in tunnel grouting. It was at least partly overcome by the use of saturated lightweight coarse aggregates as a source of additional water.

Bensted (1983) examined the relationship between w/c and ettringite formation at very early ages ( 2 hours). In his studies, about 30 percent more ettringite was formed at w/c of 0.5 than at w/c of 0.3 . The work was not directed to expansive systems, but the results may be applicable in the context of Philleo's considerations. 


\section{Conclusions and Recommendations}

Water availability and temperature are perhaps more critical variables than was believed when mixtures were first designed for the WIPP. Given that inplace concrete may not have access to externally derived water, and may be warmed by heat of hydration in mass placements, expansion may not be simply predicted. Mixtures with the chemical potential to be slightly expansive may actually shrink. All mixtures should be evaluated for expansive properties under moisture and temperature conditions that will apply in the placement.

Cohen (1983b) has emphasized the need to model expansion, to ensure that the needed amount of expansion is in fact obtained in situ and, further, to ensure that excessive expansive forces are not generated that could cause disruption of non-restrained placements. Placement conditions therefore should be considered for each use of concrete in the WIPP. Some placements will be entirely restrained, while others will be open on at least one side. Open surfaces, or surfaces in contact with a temporary bulkhead (formwork) instead of rock, will create microclimates of moisture and temperature conditions. From work on the first expansive salt-saturated concrete developed by WES for the WIPP, we know (Wakeley and Walley 1986) that slight changes in these conditions can affect measurable properties of a strongly expansive concrete. The present work indicates that the factors of temperature and humidity are more critical to the performance of less exotic mixtures as well. It demonstrates the control on early-age properties of cement-based materials that can be exerted by variables of the service environment. 


\section{References}

American Petroleum Institute. (1989). "Specification for materials and testing for well cements," Designation API, Spec 10, Washington, DC.

American Society for Testing and Materials (ASTM). (1990a). "Standard test method for compressive strength of hydraulic cement mortars (using 2-in. or 50-mm cube specimens)," Designation C 109-90, Philadelphia, PA.

. (1990b). "Standard test method for restrained expansion of expansive cement mortar," Designation C 806-87, Philadelphia, PA.

. (1990c). "Standard specification for moist cabinets, moist rooms, and water storage tanks used in the testing of hydraulic cements and concretes," Designation C 511-85, Philadelphia, PA.

. (1990d). "Standard specification for gypsum plasters," Designation C 28-86, Philadelphia, PA.

. (1990e). "Standard specification for chemical admixtures for concrete," Designation C 494-90, Philadelphia, PA.

- (1990f). "Standard specification for fly ash and raw or calcined natural pozzolan for use as a mineral admixture in portland cement concrete," Designation C 618-89a, Philadelphia, PA.

. (1990g). "Standard specification for standard sand," Designation C 778-89, Philadelphia, PA.

. (1990h). "Standard specification for expansion hydraulic cement," Designation C 845-90, Philadelphia, PA.

. (1990i). "Standard specification for reagent water," Designation D 1193-77, Philadelphia, PA.

Bensted, J. (1983). "Early hydration of portland cement - effects of water/cement ratio," Cement and Concrete Research 13, 493-498. 
Buck, A. D. (1985a). "Development of a sanded nonsalt expansive grout for repository sealing application," Miscellaneous Paper SL-85-6, U.S. Army Engineer Waterways Experiment Station, Vicksburg, MS.

Buck, A. D. (1985a). "Development of two candidate concrete mixtures (salt, nonsalt) for repository sealing applications," Miscellaneous Paper SL-85-8, U.S. Army Engineer Waterways Experiment Station, Vicksburg, MS.

Buck, A. D., Rhoderick, J. D., Burkes, J. P., Mather, K., Reinhold, R. E., and Boa, J. A. (1983). "Modification of Bell Canyon Test (BCT) 1-FF grout," Miscellaneous Paper SL-83-18, U.S. Army Engineer Waterways Experiment Station, Vicksburg, MS. Also published as SAND 83-7097, Sandia National Laboratories, Albuquerque, NM.

Cohen, M. D. (1983a). "Theories of expansion in sulfoaluminate-type expansive cements: schools of thought," Cement and Concrete Research 13, 809-818.

Cohen, M. D. (1983b). "Modeling expansive cements," Cement and Concrete Research 13, 519-528.

Gulick, C. W., Boa, J. A., and Buck, A. D. (1980). "Bell Canyon Test (BCT) cement grout development report," Sandia National Laboratories SAND-80-1928, Albuquerque, NM.

Gulick, C. W., and Wakeley, L. D. (1989). "Reference properties of cement-based plugging and sealing materials for the Waste Isolation Pilot Plant (WIPP)," Technical Report SL-89-17, U.S. Army Engineer Waterways Experiment Station, Vicksburg, MS.

Mather, B. (1984). "A discussion of the paper 'Theories of expansion in sulfoaluminate-type expansive cements: schools of thought', by M. D. Cohen," Cement and Concrete Research 14, 603-609.

Negro, A., and Bachiorrini, A. (1982). "Expansion associated with ettringite formation at different temperatures," Cement and Concrete Research 12, $677-684$.

Odler, I., and Gasser, M. (1988). "Mechanism of sulfate expansion in hydrated portland cement," Journal of the American Ceramic Society 71(11), 1015-1020.

Panchenko, A. I. (1990). "Control of expansion and structure formation of expansive cement," Cement and Concrete Research 20, 602-609.

Philleo, R. E. (1983). "Some fundamentals of cement hydration," Unpublished remarks made at the U.S. Army Corps of Engineers Division Laboratories Conference, Atlanta, GA. 
Wakeley, L. D., and Walley, D. M. (1986). "Development and field placement of an Expansive Salt-Saturated Concrete (ESC) for the Waste Isolation Pilot Plant (WIPP)," Technical Report SL-86-36, U.S. Army Engineer Waterways Experiment Station, Vicksburg, MS. 
Public reporting burden for this collection of information is estimated to average 1 hour per response, including the time for reviewing instructions, searching existing data sources. collection of information, including suggestions for reducing this burden. to Washington of information. Send comments regarding this burden estimate or any other aspect of this Davis Highway, Suite 1204. Arlington, VA 22202-4302, and to the Office of Management Headquarters Services, Directorate for information Operations and Reports, 12 15 Jefferson

ACENCY USE

\begin{tabular}{l|l|l} 
1. AGENCY USE ONLY (Leave blank) & 2. REPORT DATE & 3. REPORT TYPE AND DATES COVERED
\end{tabular}

4. TITLE AND SUBTITLE

April 1993

Final report

Length Change and Strength Development of Candidate Cement-Based

Sealing Mixtures for the WIPP

6. AUTHOR(S)

Toy S. Poole, Lillian D. Wakeley

\section{PERFORMING ORGANIZATION NAME(S) AND ADDRESS(ES)}

U.S. Army Engineer Waterways Experiment Station

Structures Laboratory

3909 Halls Ferry Road

Vicksburg, MS 39180-6199

9. SPONSORING/MONITORING AGENCY NAME(S) AND ADDRESS(ES)

U.S. Army Corps of Engineers, Washington, DC 20314-1000

\section{FUNDING NUMBERS}

\section{SUPPLEMENTARY NOTES}

Available from National Technical Information Service, 5285 Port Royal Road, Springfield, VA 22161.

12a. DISTRIBUTION/AVAILABILITY STATEMENT

12b. DISTRIBUTION CODE

Approved for public release; distribution is unlimited.

\section{ABSTRACT (Maximum 200 words)}

As part of materials development studies for the Waste Isolation Pilot Plant (WIPP) Plugging and Sealing Program, we studied two freshwater sanded grouts proportioned with materials having potential for expansion. Length change (expansion or shrinkage) and strength development were measured following curing and storage at temperatures from 23 to $50{ }^{\circ} \mathrm{C}$ and relative humidities from 50 to 100 percent.

Length change was negative at all temperatures at RH values of 75 percent and less. Decidedly positive length change (expansion) occurred only when samples were stored at 100 percent RH, and even this reversed with time at the higher temperatures. Low relative humidity also inhibited strength gain, as did storage at $50^{\circ} \mathrm{C}$, but temperatures up to $38{ }^{\circ} \mathrm{C}$ favored higher strength.

This work demonstrates the control on both early-age and long-term properties of cement-based materials that can be exerted by variables of the service environment.

\begin{tabular}{|c|c|}
\hline $\begin{array}{l}\text { 14. SUBSECT TERMS } \\
\text { Expansive cement } \\
\text { Length change } \\
\text { Relative humidity }\end{array}$ & $\begin{array}{l}\text { Strength } \\
\text { Temperature }\end{array}$ \\
\hline $\begin{array}{l}\text { 17. SECURITY CLASSIFICATION } \\
\text { OF REPORT } \\
\text { UNCLASSIFIED }\end{array}$ & $\begin{array}{l}\text { 18. SECURITY CLASSIFICATION } \\
\text { OF THIS PAGE } \\
\text { UNCLASSIFIED }\end{array}$ \\
\hline
\end{tabular}

\begin{tabular}{|c|c|}
\hline & $\begin{array}{l}\text { 15. NUMBER OF PAGES } \\
34\end{array}$ \\
\hline & 16. PRICE CODE \\
\hline $\begin{array}{l}\text { 19. SECURITY CLASSIFICATION } \\
\text { OF ABSTRACT }\end{array}$ & 20. LIMITATION OFABSTRACT \\
\hline
\end{tabular}

